ISSN 2087-3336 (Print) | 2721-4729 (Online)

TEKNOSAINS: Jurnal Sains, Teknologi dan Informatika

Volume 9, Nomor 1, Januari 2022, hlm 1-8

http://jurnal.sttmcileungsi.ac.id/index.php/tekno

DOI: 10.37373

\title{
Kajian Pola Persebaran Air Tanah di Desa Dukuhwaluh Kecamatan Kembaran Kabupaten Banyumas
}

\section{A Study of Groundwater Distribution Patterns in Dukuhwaluh Village Kembaran Subdistrict Banyumas Regency}

\author{
Dede Ifan Setianto ${ }^{1 *}$, Sigid Sriwanto ${ }^{2}$, Esti Sarjanti ${ }^{3}$ \\ ${ }^{1 *, 2,3}$, Department of Geography Education, Universitas Muhammadiyah Purwokerto, Indonesia \\ $1^{*, 2,3}$ Jl. KH. Ahmad Dahlan, Dusun III, Dukuhwaluh, Kec. Kembaran, Kabupaten Banyumas, Jawa Tengah \\ 53182 \\ *Koresponden email: dedeifan99@gmail.com
}

Artikel dikirim: 10/11/2021

Artikel direvisi: 23/11/2021

Artikel diterima: 9/12/2021

\begin{abstract}
ABSTRAK
Penelitian ini bertujuan untuk mengetahui pola persebaran air tanah di Desa Dukuhwaluh. Metode yang digunakan dalam penelitian ini adalah metode survei. Populasi penelitian ini yaitu air tanah dan kondisi geologis Desa Dukuhwaluh. Teknik pengambilan sampel menggunakan sampel sistematis yaitu dengan memperhatikan kriteria yang ditetapkan, pengambilan sampel sumur yang tersebar di Desa Dukuhwaluh sebanyak 21 titik sumur terdiri dari 9 sumur bor dan 12 sumur galian. Analisis data dilakukan dengan metode deskriptif kualitatif menjelaskan arah aliran air tanah. Hasil penelitian menunjukan bahwa pola persebaran ketinggian muka air tanah di Desa Dukuhwaluh bervariasi dibuktikan dengan ketinggian tertinggi muka air tanah berada pada 100,67 mdpl dan terendah pada ketinggian 63,4 mdpl. Pola aliran air tanah yang dihasilkan dari pembuatan peta pola aliran air tanah menunjukkan bahwa air tanah secara garis besar bergerak dari utara menuju ke tenggara.
\end{abstract}

Kata kunci: Air tanah; Pola Persebaran Air tanah; Pola Aliran Air tanah

\begin{abstract}
This study aims to determine the pattern of groundwater distribution in Dukuhwaluh Village. The method used in this study is a survey method. The population of this research is groundwater and geological conditions in Dukuhwaluh Village. The sampling technique used a systematic sample, namely by taking into account the established criteria, taking samples of wells scattered in Dukuhwaluh Village as many as 21 wells consisting of 9 drilled wells and 12 dug wells. Data analysis was carried out using a qualitative descriptive method to explain the direction of groundwater flow. The results showed that the distribution pattern of the groundwater level in Dukuhwaluh Village varied as evidenced by the highest groundwater level being at 100.67 above the sea level and the lowest at 63.4 above the sea level. The groundwater flow pattern resulting from the mapping of groundwater flow patterns shows that groundwater generally moves from north to southeast.
\end{abstract}

Keywords: Groundwater; Groundwater Distribution Pattern; Groundwater Flow Pattern.

\section{PENDAHULUAN}

Air merupakan sumber daya alam yang berlimpah di muka bumi, menutupi sekitar $71 \%$ dari permukaan bumi. Secara keseluruhan air di muka bumi, sekitar $98 \%$ terdapat di Samudera dan laut dan hanya $2 \%$ yang merupakan air tawar yang terdapat di sungai, danau dan bawah tanah. Di antara

TEKNOSAINS: Jurnal Sains, Teknologi \& Informatika is licensed under a Creative Commons Attribution-NonCommercial 4.0 International License. 
Kajian Pola Persebaran Air Tanah di Desa Dukuhwaluh Kecamatan Kembaran

Kabupaten Banyumas

air tawar yang ada tersebut, $87 \%$ diantaranya berbentuk es, $12 \%$ terdapat di dalam tanah, dan sisanya sebesar $1 \%$ terdapat di danau dan sungai[1].

Peranan air tanah dalam kehidupan manusia semakin penting karena air tanah menjadi sumber air utama untuk memenuhi kebutuhan pokok hajat hidup orang banyak, seperti air minum, rumah tangga, industri, irigasi, pertambangan, perkotaan dan lainnya. Air tanah saat ini sudah menjadi komoditas ekonomis, bahkan di beberapa wilayah sudah menjadi komoditas strategis. Diperkirakan sebanyak 70\% kebutuhan air bersih penduduk dan $90 \%$ kebutuhan air industri berasal dari air tanah. Seiring perkembangan waktu, sumber daya air telah mengalami perubahan baik dari segi kualitas maupun kuantitas. Hal ini disebabkan oleh pertumbuhan penduduk dan adanya perubahan alam secara alami [2].

Dukuhwaluh merupakan desa yang terletak di Kecamatan Kembaran, Kabupaten Banyumas dan termasuk kedalam wilayah dataran aluvial kaki Gunung Slamet yang membujur dari arah utara ke tenggara dan berada di sisi timur dari wilayah Kabupaten Banyumas[3]. Desa Dukuhwaluh terdiri dari 3 dusun, yaitu Dusun Dukuhwaluh, Dusun Dukuhwulung dan Dusun Dampit serta merupakan desa yang masuk kedalam wilayah DAS Pelus.

Di Desa Dukuhwaluh berdiri Perguruan Tinggi Swasta Universitas Muhammadiyah Purwokerto dan sekarang sedang dibangun sebuah Rumah Sakit berskala Internasional. Secara geologi Desa Dukuhwaluh merupakan daerah vulkanik purba hasil dari endapan Gunung Api Slamet. Secara lateral, sebaran batuan ini akan mengontrol pola aliran air tanah di daerah tersebut. Desa Dukuhwaluh selama dekade terakhir ini mengalami perkembangan yang pesat sejak desa tersebut ditetapkan oleh Bupati Banyumas sebagai bagian dari wilayah perkotaan. Perkembangan wilayah perkotaan menyebabkan banyaknya perubahan penggunaan lahan dari lahan non terbangun menjadi lahan terbangun[4]. Kondisi ini secara hidrologis dapat menyebabkan terjadinya gangguan terhadap hidrologi. Berdasarkan latar belakang yang telah dipaparkan di atas, maka permasalahan yang menjadi perhatian dalam penelitian ini adalah bagaimana pola persebaran air tanah di Desa Dukuhwaluh, Kecamatan Kembaran, Kabupaten Banyumas. Tujuan dari penelitian ini yaitu untuk mengetahui pola persebaran air tanah di Desa Dukuhwaluh, Kecamatan Kembaran, Kabupaten Banyumas.

Penelitian sebelumnya dilakukan Wiwin Bergasnia (2020) tentang kajian sebaran dan pola aliran air tanah dengan menggunakan metode geolistrik di kampus universitas muhammadiyah purwokerto, bahwa sebaran air tanah berada pada kedalaman 5 meter dari permukaan tanah, sedangkan pola aliran air tanah bergerak mengarah dari arah barat laut menuju tenggara[5]. Penelitian yang dilakukan ini memberikan rekomendasi bahwa sebaran dan pola aliran air tanah perlu diteliti pada daerah yang lebih luas. Penelitian ini diharapkan mampu memberikan gambaran sebaran dan pola aliran air tanah di Desa Dukuhwaluh.

Rumusan masalah dalam penelitian ini adalah bagaimana pola persebaran air tanah di Desa Dukuhwaluh, Kecamatan Kembaran, Kabupaten Banyumas. Tujuan penelitiannya adalah mengetahui pola persebaran air tanah di Desa Dukuhwaluh, Kecamatan Kembaran, Kabupaten Banyumas. Manfaat penelitian ini adalah memberi informasi mengenai pola persebaran air tanah, menjaga ketersediaan air, serta memanfaatkan air secara secukupnya dan sebagai pertimbangan kepada pengambil kebijakan berupa rujukan mengenai kajian pola persebaran air tanah.

\section{LITERATUR REVIEW}

\subsection{Air tanah}

Air tanah adalah semua air yang terdapat di bawah permukaan yang dapat dimanfaatkan untuk sumber air bagi aktivitas kehidupan. Air tanah berasal dari air hujan dan air permukaan yang terkumpul di bawah permukaan tanah, yang meresap (infiltrate) mula-mula ke zona tak jenuh (zone of 
aeration) dan kemudian meresap semakin dalam (percolate) hingga mencapai zona jenuh air dan menjadi air tanah. (Sutandi, 2012).

Air tanah umumnya dipahami sebagai air yang menempati semua rongga dalam strata geologis[6]. Air tanah (groundwater) adalah air yang menempati rongga-rongga pada lapisan geologi. Lapisan tanah yang terletak di bawah permukaan air tanah dinamakan daerah jenuh (salurated zone), sedangkan daerah tidak jenuh biasanya terletak di atas daerah jenuh sampai permukaan tanah, dimana rongga - rongganya berisi air dan udara. Karena air tersebut meliputi lengas tanah (soil moisture) dalam daerah akar (root zone), maka hal ini mempunyai arti yang sangat penting bagi pertanian, botani, dan ilmu tanah. Antara daerah jenuh dan daerah tidak jenuh tidak ada garis batas yang tegas, karena keduanya mempunyai batas yang independen, dimana air dari kedua daerah tersebut dapat bergerak ke daerah yang lain atau sebaliknya[7].

\subsection{Aliran Air tanah}

Air yang kita gunakan sehari-hari telah menjalani siklus meteorik, yaitu telah melalui proses penguapan (precipitation) dari laut, danau, maupun sungai lalu mengalami kondensasi di atmosfer, dan kemudian menjadi hujan yang turun ke permukaan bumi. Air hujan yang turun ke permukaan bumi tersebut ada yang langsung mengalir di permukaan bumi (run off) dan ada yang meresap ke bawah permukaan bumi (infiltration). Air yang langsung mengalir di permukaan bumi tersebut ada yang mengalir ke sungai, sebagian mengalir ke danau, dan akhirnya sampai kembali ke laut. Sementara itu, air yang meresap ke bawah permukaan bumi melalui dua sistem, yaitu sistem air tidak jenuh (vadous zone) dan sistem air jenuh. Sistem air jenuh adalah air bawah tanah yang terdapat pada suatu lapisan batuan dan berada pada suatu cekungan air tanah. Sistem ini dipengaruhi oleh kondisi geologi, hidrogeologi, dan gaya tektonik, serta struktur bumi yang membentuk cekungan air tanah tersebut. Air ini dapat tersimpan dan mengalir pada lapisan batuan yang kita kenal dengan akuifer (aquifer)[8].

Air yang meresap ke dalam tanah akan mengalir mengikuti gaya gravitasi bumi. Akibat adanya gaya adhesi butiran tanah pada zona tidak jenuh air (zone of aeration)[9], menyebabkan pori-pori tanah terisi air dan udara dalam jumlah yang berbeda-beda. Setelah hujan, air bergerak ke bawah melalui zona tidak jenuh air. Sejumlah air beredar di dalam tanah dan ditahan oleh gaya-gaya kapiler pada pori-pori yang kecil atau tarikan molekuler di sekeliling partikel-partıkel tanah. Bila kapasitas retensi dari tanah telah habis, air akan bergerak ke bawah ke dalam daerah dimana pori-pori tanah atau batuan terisi air. Air di dalam zona jenuh air (zone of saturation) ini disebut ABT (Air Bawah Tanah)[10].

Beberapa faktor yang berpengaruh terhadap gerakan air bawah permukaan tanah antara lain adalah:

1) Perbedaan kondisi energi di dalam air tanah itu sendiri

2) Kelulusan lapisan pembawa air

3) Kekentalan (thickness) air tanah

Air tanah memerlukan energi untuk dapat bergerak mengalir melalui ruang antar butir. Tenaga penggerak ini bersumber dari energi potensial. Energi potensial air tanah dicerminkan dari tinggi muka airnya (piezometric) pada tempat yang bersangkutan. Air tanah mengalir dari titik dengan energi potensial tinggi kearah titik dengan energi potensial rendah. Antara titik-titik dengan energi potensial sama tidak terdapat pengaliran air tanah[10][11].

\section{METODE}

Penelitian ini dilaksanakan pada bulan Maret sampai Juli 2021. Lokasi penelitian adalah di Desa Dukuhwaluh, Kecamatan Kembaran, Kabupaten Banyumas. Desa Dukuhwaluh termasuk kedalam 
Kajian Pola Persebaran Air Tanah di Desa Dukuhwaluh Kecamatan Kembaran

Kabupaten Banyumas

wilayah Daerah Aliran Sungai Pelus. Populasi pada penelitian ini adalah air tanah dan kondisi geologis Desa Dukuhwaluh.

Teknik pengambilan sampel untuk dilakukan dengan menggunakan sampel sistematis. Sampel sistematis adalah sampel yang pemilihannya dilakukan secara sistematis dari populasinya[12]. Sampel pada penelitian ini berupa sumur-sumur yang tersebar di Desa Dukuhwaluh dengan kriteria jarak antar titik sampel $\geq 100 \mathrm{~m}$, yaitu didapat sebanyak 21 titik sumur diantaranya 9 sumur bor dan 12 sumur galian. Metode yang digunakan dalam penelitian ini adalah metode survei. Pengumpulan data meliputi pengukuran koordinat $\mathrm{x}$ dan y sebagai koordinat lokasi sumur dan elevasi dengan menggunakan aplikasi UTM Geo Map, dan pengukuran kedalaman muka air sumur.

\subsection{Alat dan Bahan}

A. Alat

Peralatan yang diperlukan terdiri atas:

1) GPS sebanyak satu unit, digunakan untuk menentukan titik koordinat tempat pengukuran permukaan tanah.

2) Meteran sebanyak satu unit, digunakan untuk membantu penentuan panjang lintasan dan spasi antar elektroda.

3) Lembar pengamatan, digunakan untuk mencatat data hasil penelitian dilapangan.

4) Aplikasi UTM Geo Map, digunakan untuk menentukan elevasi dan koordinat lokasi sampel sumur.

5) Software Microsoft excel, digunakan untuk mengolah data.

6) Kamera, sebagai alat dokumentasi.

7) Laptop, digunakan untuk mengolah data dan menyusun laporan

B. Bahan

Bahan yang digunakan pada penelitian ini adalah Citra landsat Google Earth bulan Juni 2021 digunakan untuk membuat Peta Pola Aliran Air tanah di Desa Dukuhwaluh.

\subsection{Teknik pengumpulan data.}

Teknik pengumpulan data merupakan langkah yang paling utama dalam penelitian, karena mendapatkan data adalah tujuan utama dari dilakukanya penelitian. Prosedur pengambilan data di lapangan untuk menentukan pola persebaran ketinggian muka air tanah di daerah penelitian adalah sebagai berikut:

1) Persiapan alat

Alat-alat dipersiapkan untuk melakukan pengukuran di lapangan adalah Aplikasi UTM Geo Map, meteran sebanyak satu unit dan lembar pengamatan untuk mencatat data hasil pengukuran.

2) Pengamatan / observasi di lapangan.

Pengukuran kedalaman muka air tanah dilakukan pada sampel sumur di Desa Dukuhwaluh yang meliputi pengukuran koordinat $\mathrm{x}$ dan y sebagai koordinat lokasi sumur dan elevasi dengan menggunakan aplikasi UTM Geo Map, sedangkan untuk pengukuran kedalaman air sumur dengan cara pengukuran langsung kedalaman muka air sumur dan ketinggian bibir sumur dengan menggunakan meteran atau dengan melakukan wawancara kepada pemilik sumur.

3) Pengumpulan data dan entry data.

Data-data hasil pengukuran di lapangan dikumpulkan dan entry data di laptop. Data atau bahan yang diperlukan sebelum dianalisis menggunakan Software ArcGis 10.4.1 adalah koordinat lokasi x dan y, elevasi sebenarnya dan kedalaman muka air tanah sebenarnya.

\section{HASIL DAN PEMBAHASAN}


Pola persebaran ketinggian muka air tanah di Desa Dukuhwaluh menggunakan software ArcGis 10.4.1 untuk mengolah data yang diambil secara langsung dari pengukuran koordinat sumur dan elevasi menggunakan aplikasi UTM Geo Map, data kedalaman muka air sumur diukur secara langsung dengan mengukur kedalaman dari bibir sumur sampai ke permukaan air sumur dengan menggunakan meteran dan ketinggian bibir sumur diukur menggunakan meteran sampai ke permukaan tanah. Pada penelitian ini menggunakan 21 sampel sumur yang tersebar di area Desa Dukuhwaluh.

Data-data tersebut kemudian diolah menggunakan software microsoft excel untuk menghasilkan data ketinggian MAT sebenarnya. Data ketinggian MAT sebenarnya diperoleh dengan melakukan pengurangan antara data elevasi dengan kedalaman MAT sebenarnya. Untuk memperoleh data kedalaman MAT sebenarnya dilakukan dengan mengurangi data kedalaman muka air tanah dengan tinggi bibir sumur. Data perhitungan ketinggian MAT sebenarnya disajikan pada tabel 1 .

Tabel 1. Data koordinat sumur dan data kontur muka air tanah

\begin{tabular}{|c|c|c|c|c|c|c|c|}
\hline \multicolumn{8}{|c|}{ DATA KOORDINAT SUMUR DAN DATA KONTUR MUKA AIR TANAH } \\
\hline \multirow{3}{*}{ NO } & \multicolumn{2}{|c|}{ Lokasi } & \multirow{3}{*}{ Elevasi } & \multirow{3}{*}{$\begin{array}{l}\text { Tinggi } \\
\text { Bibir } \\
\text { Sumur } \\
\text { (m) }\end{array}$} & \multirow{3}{*}{$\begin{array}{c}\text { Kedalam } \\
\text { an } \\
\text { Muka Air } \\
\text { tanah }\end{array}$} & \multirow{3}{*}{$\begin{array}{c}\text { Kedalaman } \\
\text { MAT } \\
\text { Sebenarnya }\end{array}$} & \multirow{4}{*}{$\begin{array}{c}\text { Ketinggia } \\
\text { n } \\
\text { MAT } \\
\text { Sebenarn } \\
\text { ya } \\
(g)=(c) \text { - } \\
(f)\end{array}$} \\
\hline & $\mathbf{X}$ & $\mathbf{Y}$ & & & & & \\
\hline & & & & & & & \\
\hline$\stackrel{(a}{)}$ & & (b) & (c) & (d) & $(e)$ & $\begin{array}{c}(f)=(e)- \\
(d)\end{array}$ & \\
\hline 1 & 309078,9 & 9180307,2 & 65,39 & 0,65 & 2,1 & 1,45 & 63,94 \\
\hline 2 & 308679,7 & 9181145,6 & 101,61 & 0 & 3 & 3 & 98,61 \\
\hline 3 & 308655,8 & 9181180,7 & 102,58 & 0,63 & 2,54 & 1,91 & 100,67 \\
\hline 4 & 308844,7 & 9180221,6 & 95,83 & 0 & 1 & 1 & 94,83 \\
\hline 5 & 308977,8 & 9180346,2 & 73,63 & 0 & 3 & 3 & 70,63 \\
\hline 6 & 309219,0 & 9180069,8 & 92,05 & 0,83 & 5,38 & 4,55 & 87,5 \\
\hline 7 & 309379,6 & 9180363,8 & 93,43 & 0,79 & 5,22 & 4,43 & 89 \\
\hline 8 & 309220,7 & 9180680,1 & 100,26 & 0 & 2,8 & 2,8 & 97,46 \\
\hline 9 & 309349,8 & 9180836,4 & 97,44 & 0,77 & 4,43 & 3,66 & 93,78 \\
\hline 10 & 309109,4 & 9181408,7 & 97,03 & 0 & 1,55 & 1,55 & 95,48 \\
\hline 11 & 308737,3 & 9181331,7 & 93,63 & 0 & 1,7 & 1,7 & 91,93 \\
\hline 12 & 308860,9 & 9180958,5 & 96,13 & 0 & 1,3 & 1,3 & 94,83 \\
\hline 13 & 309030,7 & 9180749,5 & 95,83 & 0 & 1,35 & 1,35 & 94,48 \\
\hline 14 & 309273,9 & 9180662,2 & 90,91 & 0,6 & 4,9 & 4,3 & 86,61 \\
\hline 15 & 309249,3 & 9179823,2 & 79,65 & 0 & 4 & 4 & 75,65 \\
\hline 16 & 309077.4 & 9179955.9 & 87.53 & 0 & 4,6 & 4.6 & 82.93 \\
\hline 17 & 308793,2 & 9180032,2 & 88,62 & 0,72 & 1,84 & 1,12 & 87,5 \\
\hline 18 & 308989.6 & 9179753,4 & 88,96 & 0,72 & 4.54 & 3,82 & 85,14 \\
\hline 19 & 309336,3 & 9180247,2 & 92,85 & 0,35 & 4,83 & 4,48 & 88,37 \\
\hline 20 & 309354.9 & 9180064.6 & 90.98 & 0,43 & 4.85 & 4,42 & 86.56 \\
\hline 21 & 308819.7 & 9180427.8 & 97.03 & 0,40 & 2,43 & 2.03 & 95.00 \\
\hline
\end{tabular}

Sumber : Data Primer,2021. 
Dede Ifan Setianto, Sigid Sriwanto, Esti Sarjanti

Kajian Pola Persebaran Air Tanah di Desa Dukuhwaluh Kecamatan Kembaran

Kabupaten Banyumas

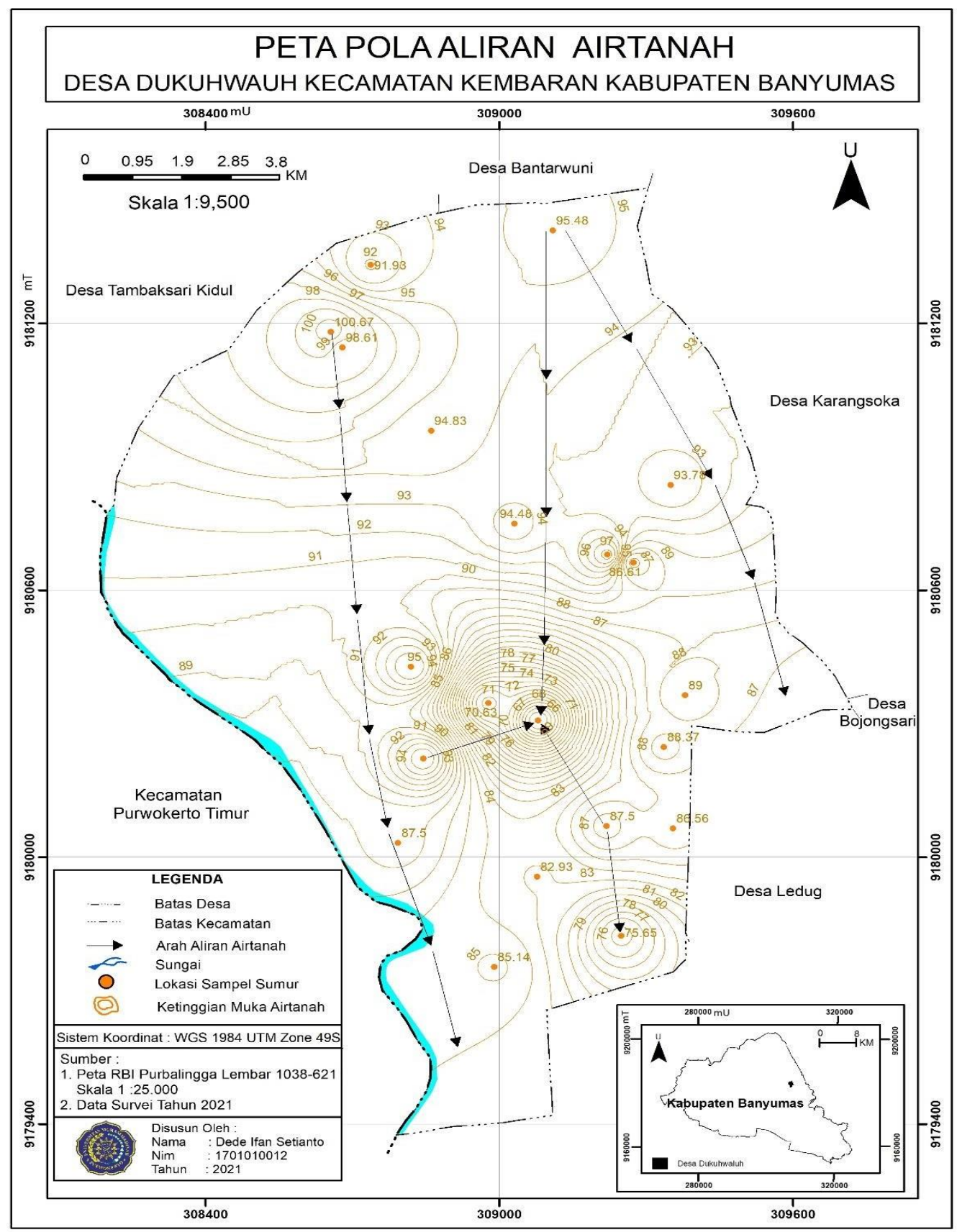

Gambar 1. Peta pola aliran air tanah desa dukuhwaluh

Berdasarkan peta pola aliran air tanah di Desa Dukuhwaluh di bawah ini, dapat diketahui bahwa ketinggian muka air tanah di Desa Dukuhwaluh bervariasi dari ketinggian tertinggi muka air tanah yaitu berada pada 100,67 mdpl sedangkan ketinggian terendah berada pada 63,4 mdpl. Arah aliran air tanah selalu tegak lurus $90^{\circ}$ kontur air tanahnya dan mengalir dari kontur tertinggi ke rendah[13]. Dilihat dari arah mata angin pola aliran air tanah, dari kontur muka air tanah tinggi ke kontur muka air tanah rendah yang secara rinci disajikan pada Gambar 1. secara garis besar mengarah dari utara menuju ke tenggara.

Air tanah mengalir pada suatu penampang yang seragam dengan gaya gravitasi yang diperoleh dari kemiringan kontur air tanah[14]. Air tanah mengalami pergerakan di dalam akuifer dengan kecepatan tertentu sehingga memiliki potensi air tanah yang bersifat dinamis[15]. Lokasi penelitian 
yaitu berada di Desa Dukuhwaluh, pola aliran air tanah ini berdekatan dengan SUB- Daerah Aliran Sungai (DAS) Pelus yang berasal dari DAS Serayu sehingga alirannya berasal dari Gunungapi Slamet, sehingga dapat dilihat hubungan air tanah dengan sungai tersebut yang diduga membawa materialmaterial alluvium seperti kerikil, batu pasir dan pola aliran air tanah juga cenderung mengikuti pola kontur di daerah penelitian.

Pola persebaran ketinggian muka air tanah di Desa Dukuhwaluh bervariasi dibuktikan dengan ketinggian tertinggi muka air tanah berada pada 100,67 mdpl dan terendah pada ketinggian 63,4 mdpl. Pola aliran air tanah yang dihasilkan dari pembuatan peta aliran air tanah menunjukan bahwa air tanah secara garis besar bergerak dari utara menuju ke tenggara. Jika dirinci maka pola aliran air tanah Desa Dukuhwaluh bagian barat mengalir dari utara ke tenggara. Pola aliran air tanah Desa Dukuhwaluh bagian tengah mengalir dari utara ke selatan. Pola aliran air tanah Desa Dukuhwaluh bagian barat mengalir dari utara ke tenggara. Pada bagian tengah Desa Dukuhwaluh terjadi pemusatan aliran air tanah dikarenakan elevasi yang rendah dan juga pengambilan air tanah yang besar.

Hasil penelitian ini jika dikaitkan dengan penelitian relevan (Wiwin Bergasnia, 2020) terdapat perbedaan arah aliran air tanah yaitu air tanah bergerak mengarah dari arah utara menuju tenggara sedangkan pada penelitian relevan air tanah bergerak mengarah dari arah barat laut menuju tenggara dan jika dikaitkan dengan penelitian relevan[16] terdapat perbedaan arah aliran air tanah yaitu pola aliran air tanah mengalir dari arah utara menuju barat daya yang merupakan lembah dengan mata air.

\section{SIMPULAN}

Berdasarkan hasil penelitian maka dapat disimpulkan bahwa pola persebaran air tanah yang dihasilkan dari pembuatan peta kontur ketinggian muka air tanah menunjukan bahwa air tanah tersebar secara merata. Ketinggian air tanah bervariasi dari ketinggian tertinggi muka air tanah yaitu berada pada 100,67 mdpl dan ketinggian terendah berada pada 63,4 mdpl. Pola aliran air tanah secara garis besar bergerak dari arah utara menuju ke arah tenggara.

\section{REFERENSI}

[1] Hefni Effendi, Telaah kualitas air bagi pengelolaan sumber daya dan lingkungan perairan. 2003.

[2] B. Yuwono, A. H. Pratomo, H. C. Rustamaji, P. Pratiknyo, and M. A. I. Jati, "Pemetaan Data Recharge Air Tanah Di Kabupaten Sleman Berdasarkan Data Curah Hujan," Telematika, vol. 13, no. 2, p. 93, 2017, doi: 10.31315/telematika.v13i2.1725.

[3] N. N. T. Mahayani, I. B. M. Astawa, and D. M. Atmaja, "Analisis Tekanan Penduduk Terhadap Lahan Pertanian Di Kecamatan Buleleng," J. Pendidik. Geogr. Undiksha, vol. 5, no. 2, 2017, doi: 10.23887/jjpg.v5i2.20661.

[4] S. F. Shalihati, S. Sutomo, and S. Suwarno, "Analisis Dominasi Penggunaan Lahan Kekotaan dan Kedesaan di Kecamatan Kembaran," JSSH (Jurnal Sains Sos. dan Humaniora), vol. 1, no. 2, p. 147, 2017, doi: 10.30595/jssh.v1i2.1879.

[5] S. Suwarsito, "Kajian Pola Aliran Air Tanah Di Area Kampus Utama Universitas Muhammadiyah Purwokerto," Sainteks, vol. 17, no. 1, p. 19, 2020, doi: 10.30595/sainteks.v17i1.8507.

[6] D. ToddKeith, Groundwater Hydrology 3rd edition. New York: John Wiley \& Sons, 2005.

[7] Soemarto, "Hidrologi Teknik Edisi Ke - 2," Erlangga : Jakarta, 1987.

[8] M. HADIAN, "Sebaran akuifer dan pola aliran air tanah di Kecamatan Batuceper dan Kecamatan Benda Kota Tangerang, Propinsi Banten," Indones. J. Geosci., vol. 1, no. January 2006, 2006, doi: 10.17014/ijog.vol1no3.20061.

[9] D. Panguriseng, "Capillary Shock Phenomena of Groundwater in Land of Irrigatioan Groundwater Users in Takalar,” Natl. Conf. FGDTPTM Eng., no. June, pp. 1-10, 2016.

[10] H. R. Soedireja, "Potensi dan Upaya Pemanfaatan Air Tanah untuk Irigasi Lahan Kering di 
Kajian Pola Persebaran Air Tanah di Desa Dukuhwaluh Kecamatan Kembaran

Kabupaten Banyumas

Nusa Tenggara," J. Irig., vol. 11, no. 2, p. 67, 2017, doi: 10.31028/ji.v11.i2.67-80.

[11] B. a B. Ii, D. Teori, and D. a N. Metodologi, "dan terus ke laut. Faktor lainnya adalah perubahan lahan-lahan terbuka menjadi pemukiman dan industri, penebangan hutan tanpa kontrol. Hal tersebut akan sangat mempengaruhi infiltrasi terutama bila terjadi pada daerah resapan (," pp. 4-17.

[12] S. H. R. Bintarto, Metode analisa geografi. Jakarta : LP3ES, 1979, 1979.

[13] Saldanela, S. Sutikno, and A. Hendri, "Pemetaan Pola Aliran Air Tanah Berbasis Sistem Informasi Geografis (Sig) Di Kawasan Kecamatan Tampan Kota Pekanbaru," Jom FTEKNIK, vol. 2, no. 1, pp. 1-8, 2015.

[14] H. Harjito, "Metode Pumping Test sebagai Kontrol Untuk Pengambilan Air tanah Secara Berlebihan," J. Sains \&Teknologi Lingkung., vol. 6, no. 2, pp. 138-149, 2014, doi: 10.20885/jstl.vol6.iss2.art7.

[15] B. Hamuna and R. H. R. Tanjung, "Deteksi Perubahan Luasan Mangrove Teluk Youtefa Kota Jayapura Menggunakan Citra Landsat Multitemporal," Maj. Geogr. Indones., vol. 32, no. 2, p. 115, 2018, doi: 10.22146/mgi.33755.

[16] R. Maria, A. F. Rusydi, H. Lestiana, and S. Wibawa, "Hidrogeologi Dan Potensi Cadangan Air tanah Di Dataran Rendah Indramayu," Ris. Geol. dan Pertamb., vol. 28, no. 2, p. 181, 2018, doi: 10.14203/risetgeotam2018.v28.803. 